\title{
Keçiboynuzu pekmezi ilave edilerek üretilen meyveli yoğurdun bazı özellikleri
}

\section{Some characteristic of fruity yoghurt produced with adding carob molasses}

\author{
Şerafettin ÇELIK ${ }^{1}$ iD , Naciye ÜNVER ${ }^{1^{*}}$, Betül GÜÇ ${ }^{1}$ iD Pınar CEYLAN $^{1}$ iD \\ ${ }^{1}$ Harran Üniversitesi Ziraat Fakültesi Gıda Mühendisliği Bölümü, Şanlıurfa/TÜRKIYE
}

\section{To cite this article:}

Çelik, Ş., Ünver, N., 2018. Keçiboynuzu pekmezi ilave edilerek üretilen meyveli yoğurdun bazı özellikleri. Harran Tarim ve Gida Bilimleri Dergisi, 22(2): 215224

Address for Correspondence: Naciye ÜNVER

e-mail:

unver.naciye@harran.edu.tr

\section{Received Date:}

14.06.2017

Accepted Date:

17.04.2018
C) Copyright 2018 by Harran University Faculty of Agriculture. Available on-line at www.dergipark.gov.tr/harranziraat öz

Bu çalışmada \%3, 4 ve 5 oranında keçiboynuzu pekmezi ilave edilmiş meyveli yoğurt ile kontrol yoğurdu üretilerek $4{ }^{\circ} C^{\prime}$ de 21 gün süre ile depolanmış ve periyodun 1., 7., 14. ve 21. günlerinde ürünlerin bazı fizikokimyasal, mikrobiyolojik ve duyusal parametreleri incelenmiştir. İstatistiksel değerlendirme sonucunda, kontrol yoğurduna oranla, ortalama viskozite değerinin $\% 3$ keçiboynuzu pekmezi içeren meyveli yoğurtta daha yüksek, serum ayrılmasının daha düşük olduğu tespit edilmiştir. Yoğurda ilave edilen keçiboynuzu pekmezi oranının artmasına bağlı olarak serum ayrılmasının azaldığı; depolama periyodu boyunca deneme yoğurt örneklerinde ortalama $\mathrm{pH}$ değerimin azaldığı, viskozite değerinin depolamanın 7.gününe kadar azaldığı daha sonra arttığı; serum ayrılmasının depolamanın 7. gününe kadar arttığı daha sonra azaldığı, ortalama titrasyon asitliğinin ise yükseldiği tespit edilmiştir. 21 günlük depolama süresi sonunda kontrol grubuna oranla, pekmez içeren yoğurtlarda Str. thermophilus ve Lb. delbrueckii subsp. bulgaricus sayısı yüksek bulunmuştur. Görünüş yönünden en yüksek puanı kontrol yoğurdu alırken bunu ikinci sırada \%3 keçiboynuzu pekmezi içeren meyveli yoğurt takip etmektedir. Yapılan değerlendirmeler sonucunda, meyveli yoğurt üretiminde \%3 oranında keçiboynuzu pekmezi kullanılabileceğine karar verilmiştir.

Anahtar Kelimeler: Keçiboynuzu pekmezi, Meyveli yoğurt, Viskozite, Serum ayrılması

\section{ABSTRACT}

In this study, four type of fruity yoghurt samples which comprise of $3 \%, 4 \%$ and $5 \%$ carob molasses and control yoghurt ( $0 \%$ carob molasses) were produced, and all of the yoghurt samples stored 21 days under refrigerated conditions $\left(+4{ }^{\circ} \mathrm{C}\right)$. Some physicochemical, microbiological and sensory parameters were examined in 1.,7.,14. and 21. days of storage period. As a result of the statistical evaluation, it was determined that mean viscosity value of fruity yoghurt which comprised $3 \%$ carob molasses was higher than control yoghurt and mean whey separation ratio of the fruity yoghurt sample was lower than control yoghurt. It was found that whey separation ratio decrease as the carob molasses ratio of yoghurt samples increase, during storage period of the study means of $\mathrm{pH}$ value decrease, viscosity value decrease until the $7^{\text {th }}$ day of starage period and then increase, whey separation ratio increase until the $7^{\text {th }}$ day of starage period and then decrease, mean of titritable acidity value increase during storage period of the study. In the end of 21 days storage period it was found that Str. thermophilus and $L b$. delbrueckii subsp. bulgaricus counts of fruity yoghurt samples are higher than control yoghurt. While control sample had the higher score $3 \%$ carob molasses-yoghurt sample had the second highest score according to evaluation of appeaerence. As a result of evaluation obtained from analyses, it was decided that the $3 \%$ carob molasses could be used in the production of fruit yogurt.

Key Words: Carob molasses, Fruity yoghurt, Viscosity, Whey separation 


\section{Giriş}

Keçiboynuzu pekmezi (KP), keçiboynuzu bitkisinin (Ceretonia siliqua L.) ekstraksiyonu sonucu elde edilir. Yüksek karbonhidrat içeriğinden dolayı (yaklaşık \%70) KP iyi bir enerji kaynağıdır. KP karbonhidrat içeriğinin yaklaşık \%70'inin monosakkaritlerden oluşması, tüketildikten sonra bu şekerlerin kolaylıkla kana karışmasına ve böylelikle kan şekerinin yükselmesine neden olmaktadır. Ayrıca içerdiği çeşitli vitamin ve mineraller sayesinde $\mathrm{KP}$, anemi gibi pek çok hastalığın tedavisinde kullanılabilecek fonksiyonel bir gıda olarak tanımlanmaktadır (Aksu ve Nas, 1996).

Yoğurt besleyici özelliğinin yanında probiyotik, antikanserojenik, antimutajenik, antogonistik ve terapatik etkileri ile bilinen fermente bir süt ürünüdür (Kumar ve Mishra, 2004). Genel olarak katı yoğurt (set type) ve pıhtısı parçalanmış yoğurt (stirred type) olmak üzere 2 tip yoğurt üretimi söz konusudur (Tamime ve Robinson, 1999). Ayrica üretiminde meyve esaslı karışımların kullanıldığı aromalı ve meyveli yoğurt tipleri de vardır. Son zamanlarda yeni ürün geliştirme ve ürünlere fonksiyonel özellikler kazandırma adına meyveli ve aromalı yoğurt üretimi ve çeşitliliği artmaktadır.

Sağlığa faydalı özellikleri mevcut olan pekmezyoğurt karışımlarının çeşitli özelliklerinin incelenerek endüstriyel anlamda üretimi ve tüketiminin arttırılması konusunda çalışmalara rastlanılmaktadır. Günümüze kadar bu konuda yapılan çalışmalar içerisinde en çok üzüm pekmezi-yoğurt karışımlarına (Öztürk ve Öner, 1999; Tarakçı ve Küçüköner, 2003; Karaca ve ark., 2012; Karaca, 2013) rastlanmaktadır. Bunun dışında daha az bilinen ve üretimi gerçekleştirilen KP (Atasoy, 2009; Çelik, 2010; Karaca ve ark., 2012; Karaca, 2013), dut (Çelik ve Bakırcı, 2003; Karaca ve ark., 2012; Karaca, 2013) ve andız pekmezi (Çelik ve ark., 2009) ile yoğurt karışımlarının hazırlanması ve bunların çeşitli özelliklerinin incelenmesi hakkında da çalışmalar mevcuttur.

Çelik (2010) \%2, 4, 6 ve 8 oranında KP ilave ederek ürettiği meyveli yoğurtlarda KP'nin fermantasyon prosesi üzerindeki etkileri ile meyveli yoğurdun bazı fizikokimyasal ve mikrobiyolojik özellikleri üzerindeki etkilerini araştırmıştır. Yapılan bu çalışmada, duyusal açıdan bir değerlendirme yapılmadığı ve meyveli yoğurt üretiminde stabilizör kullanımını tavsiye ettiği anlaşılmaktadır. Çelik (2010)'in önerileri doğrultusunda üretimde stabilizör kullanılmış ve meyveli yoğurt üretiminde araştırıcının önerdiği \%4 KP kullanım oranı daraltılarak çalışma yapılmıştır. Meyveli yoğurt üretiminde, ürünün bazı karakteristik özellikleri ile duyusal özellikleri bağlamında KP kullanım oranının daraltılarak daha net bir oran tespit edilmesi amaçlanmış ve böylece literatüre katkı sağlanması amaçlanmıştır.

\section{Materyal ve Metot}

\section{Materyal}

Yoğurt üretiminde; tam yağlı homojenize inek sütü (Harran Üniversitesi Gıda Mühendisliği Bölümü Pilot Süt İşletmesi, Şanlıurfa) ile yoğurt kültürü (YC-350, Chr. Hansen, Türkiye) kullanılmıştır. Meyveli yoğurt üretiminde; geleneksel keçiboynuzu pekmezi (Yenigün Gıda Sanayi, Altınova Sinan Mahallesi Honamlı Sokak No:4, Kepez/Antalya) ve Maymix 106 EX stabilizör (Maysa Gıda, KOSB Melek Aras Bulvarı No: 54 Tuzla/İstanbul) kullanılmıştır.

\section{Yoğurt Üretimi}

Üretimde kullanılacak $K P$, yoğurt üretimi öncesi pastörize $\left(65{ }^{\circ} \mathrm{C}, 30 \mathrm{dk}\right)$ edilmiştir. Homojenize süt, $85{ }^{\circ} \mathrm{C}^{\prime} \mathrm{de} 10 \mathrm{dk}$ süre ile pastörize edildikten sonra $43^{\circ} \mathrm{C}^{\prime}$ ye soğutulmuş ve $\% 2$ oranında starter kültür ile inoküle edilerek dört eşit kısma ayrılmıştır. Birinci kısım kontrol olarak alınmıştır. İkinci, üçüncü ve dördüncü kısımlara sırasıyla \%3, 4 ve 5 oranında KP ilave edilmiştir. Daha sonra, 200 g'lık polistiren kaplara dolum yapılarak 42 ${ }^{\circ} \mathrm{C}^{\prime}$ de 3.5 saat süreyle inkübasyona terk edilmiştir. İnkübasyon bitiminde, yoğurt örnekleri $4{ }^{\circ} C^{\prime}$ ye soğutulmuş ve bu sıcaklıkta 21 gün süre ile depolanmıştır (Tamime ve Robinson, 2007). 
Çalışmalar 2 tekerrürlü olarak düzenlenmiş, analizler ise paralel olarak yürütülmüştür.

Kontrol ile \%3, 4 ve 5 oranlarında KP içeren meyveli yoğurtların ortalama kurumadde, kül ve protein oranları, sırasıyla \%11.69, \%13.70, $\% 13.97$ ve $\% 14.67 ; \% 1.04, \% 1.16, \% 1.18$ ve $\% 1.26 ; \% 4.26, \% 6.31, \% 6.63$ ve $\% 6.70$ olarak hesaplanmıştır.

\section{Analitik Yöntemler}

Deneme yoğurt örneklerinde kurumadde (AOAC, 1990), kül (AOAC, 1990) ve protein (Sader ve ark., 2004) analizleri depolama periyodunun 1. gününde gerçekleştirilmiştir. Yoğurt örneklerinde depolama periyodunun 1., 7., 14., ve 21. günlerinde pH (WTW pH-3301, Germany), titrasyon asitliği (Kurt ve ark., 1996), viskozite (Gassem ve Frank, 1991), serum ayrılması (Rodarte ve ark., 1993) ve mikrobiyolojik analizler (Rybka ve Kailasapat, 1996) yapılmıştır.

Deneme ürünlerinin viskozite ölçümü için, 5 numaralı prob kullanılmış ve $20 \mathrm{rpm}^{\prime}$ de 10 . sn'de Viskozimetre cihazı (Brookfield Programmable DV-II+Viskometer, UK) ile okuma yapılmıştır. Yoğurt örneklerinde serum ayrılması analizinde, $5 \mathrm{~g}$ örnek 5000 rpm'de 20 dk süre ile santrifüj edildikten sonra ayrılan serum miktarı \% olarak tespit edilmiştir. Mikrobiyolojik analizler dökme plak yöntemi kullanılarak M17 agar ve MRS agara (Merck, Almanya) ekimler gerçekleştirilmiştir. Ekim işlemi tamamlanan petriler $37^{\circ} \mathrm{C}^{\prime}$ de $24-48$ saat süreyle inkübasyona bırakılmış ve bu süre sonunda gelişen bakteri kolonileri sayılmıştır. Duyusal değerlendirme ise 8 panelist tarafından Hedonik skala kullanılarak depolama periyodunun 7. gününde gerçekleştirilmiştir (Bodyfelt ve ark., 1988).

\section{istatistiksel Analizler}

Farklı oranlarda KP ilave edilerek hazırlanan meyveli yoğurtların bazı fizikokimyasal ve duyusal özellikleri üzerine etkisi, tek yönlü varyans analizi ile Minitab paket programı yardımıyla değerlendirilmiştir. Değerlendirme öncesi mikrobiyolojik verilere logaritmik transformasyon, duyusal verilere ise karekök transformasyon uygulanmıştır. Varyans analizleri sonucu önemli çıkan ortalamalar arasındaki farklılık, Tukey çoklu karşılaştırma testi ile belirlenmiştir (Yıldız ve Bircan, 1991).

\section{Araştırma Bulguları ve Tartışma}

Farklı oranlarda KP ilave edilerek üretilen set tipi meyveli yoğurtların fizikokimyasal ve mikrobiyolojik özellikleri 21 günlük depolama periyodu boyunca birer hafta aralıklarla araştırılmıştır. Yapılan istatistiksel değerlendirme sonuçlarına göre; yoğurt tipi bakımından deneme yoğurtların ortalama titrasyon asitliği ve serum ayrılması değerleri ile Str. thermophilus sayısı arasındaki farklılık $\mathrm{P}<0.01, \mathrm{pH}$ değerleri arasındaki farklılık ise $\mathrm{P}<0.05$; depolama periyodu bakımından yoğurtların ortalama $\mathrm{pH}$, titrasyon asitliği, viskozite ve serum ayrılması oranları ile Str. thermophilus sayısı ve $L b$. delbrueckii ssp. bulgaricus sayıları arasındaki farklılık $\mathrm{P}<0.01$; yoğurt tipi $x$ depolama periyodu interaksiyonu bakımından ise $\mathrm{pH}$, titrasyon asitliği ve serum ayrılması oranları ile Str. thermophilus sayısı arasındaki farklılık $\mathrm{P}<0.01$, viskozite oranları ve $L b$. Delbrueckii ssp. bulgaricus sayıları arasındaki farklılık ise $\mathrm{P}<0.05$ düzeyinde önemli bulunmuştur. İstatistiksel analizler sonucunda, deneme yoğurt örneklerine ilişkin duyusal veriler arasındaki önemli $(\mathrm{P}<0.05)$ farklılık tespit edilmemiştir. 
Çizelge 2. Yoğurt tipi ve depolama periyodu açısından deneme yoğurtlarının bazı parametrelerine ilişkin ortalama değerler ve oluşan gruplar

Table 2. Mean values and groups in terms of some characteristics of yoghurt tips and storage period

\begin{tabular}{|c|c|c|c|c|c|c|c|}
\hline & & $\begin{array}{l}\mathrm{pH} \\
\mathrm{pH}\end{array}$ & $\begin{array}{c}\text { Titrasyon } \\
\text { asitliği (\%LA) } \\
\text { Titratable } \\
\text { acidity (\%LA) }\end{array}$ & $\begin{array}{l}\text { Viskozite }(c P) \\
\text { Viscosity }(c P)\end{array}$ & $\begin{array}{c}\text { Serum } \\
\text { ayrılması (\%) } \\
\text { Whey } \\
\text { separation } \\
\text { (\%) }\end{array}$ & $\begin{array}{c}\text { Str. } \\
\text { thermophilus } \\
\text { (M17 agar) } \\
\text { Str. } \\
\text { thermophilus } \\
\text { (M17 agar) }\end{array}$ & $\begin{array}{c}\text { Lb. delbrueckii } \\
\text { ssp. } \\
\text { bulgaricus } \\
\text { (MRS agar) } \\
\text { Lb. delbrueckii } \\
\text { ssp. } \\
\text { bulgaricus } \\
\text { (MRS agar) }\end{array}$ \\
\hline \multirow{4}{*}{$\begin{array}{l}\text { Yoğurt } \\
\text { Tipi } \\
\text { Yoghurt } \\
\text { Type }\end{array}$} & $\begin{array}{l}\text { Kontrol } \\
\text { Control }\end{array}$ & $\underset{\mathrm{b}}{3.98 \pm 0.02}$ & $5.27 \pm 0.04^{b}$ & $16565.00 \pm 260.26^{a}$ & $51.21 \pm 0.75^{\mathrm{a}}$ & $8.55 \pm 0.03^{b}$ & $8.35 \pm 0.06^{b}$ \\
\hline & $\begin{array}{l}\% 2 \mathrm{KP} \\
\% 2 \mathrm{CM}\end{array}$ & $\underset{b}{3.98 \pm 0.02}$ & $5.50 \pm 0.04^{\mathrm{a}}$ & $17338.10 \pm 260.26^{\mathrm{a}}$ & $38.74 \pm 0.75^{b}$ & $8.87 \pm 0.03^{\mathrm{a}}$ & $8.27 \pm 0.06^{a}$ \\
\hline & $\begin{array}{l}\% 3 \mathrm{KP} \\
\% 3 \mathrm{CM}\end{array}$ & $\underset{\mathrm{a}}{4.05 \pm 0.02}$ & $5.25 \pm 0.04^{b}$ & $16001.30 \pm 260.26^{a}$ & $36.75 \pm 0.75^{c}$ & $8.59 \pm 0.03^{b}$ & $8.26 \pm 0.06^{b}$ \\
\hline & $\begin{array}{l}\text { \%4 KP } \\
\% 4 \mathrm{CM}\end{array}$ & $\underset{\mathrm{ab}}{4.03 \pm 0.02}$ & $5.21 \pm 0.04^{b}$ & $15578.80 \pm 260.26^{\mathrm{a}}$ & $34.88 \pm 0.75^{d}$ & $8.79 \pm 0.03^{a}$ & $8.22 \pm 0.06^{a}$ \\
\hline \multirow{4}{*}{$\begin{array}{l}\text { Depolam } \\
\text { a Süresi } \\
\text { (gün) } \\
\text { Storage } \\
\text { Time } \\
\text { (day) }\end{array}$} & 1 & $\underset{\mathrm{a}}{4.24 \pm 0.02}$ & $4.94 \pm 0.04^{d}$ & $19046.90 \pm 260.26^{\mathrm{a}}$ & $41.34 \pm 0.75^{\mathrm{a}}$ & $8.48 \pm 0.03^{b}$ & $8.14 \pm 0.06^{b}$ \\
\hline & 7 & $\underset{b}{4.09 \pm 0.02}$ & $5.23 \pm 0.04^{c}$ & $14331.20 \pm 260.26^{b}$ & $43.22 \pm 0.75^{b}$ & $8.44 \pm 0.03^{b}$ & $8.56 \pm 0.06^{b}$ \\
\hline & 14 & $\underset{b}{4.05 \pm 0.02}$ & $5.45 \pm 0.04^{b}$ & $16153.80 \pm 260.26^{b}$ & $38.45 \pm 0.75^{c}$ & $8.93 \pm 0.03^{a}$ & $8.34 \pm 0.06^{a}$ \\
\hline & 21 & $\underset{c}{3.65 \pm 0.02}$ & $5.60 \pm 0.04^{\mathrm{a}}$ & $15951.30 \pm 260.26^{b}$ & $37.57 \pm 0.75^{c}$ & $8.94 \pm 0.03^{\mathrm{a}}$ & $8.06 \pm 0.06^{\mathrm{a}}$ \\
\hline
\end{tabular}

Farklı harfler ile gösterilen ortalamalar arasındaki fark istatistiksel olarak $\mathrm{P}<0.05$ düzeyinde önemlidir. Means within the same column not sharing a common letter indicate significant difference at $p<0.05$.

KP: Keçiboynuzu pekmezi içeren yoğurt, LA: Laktik asit, , CP: Santipoise

$C M$ : Carob molasses yoghurt, LA: Lactic acid, CP: centipoise

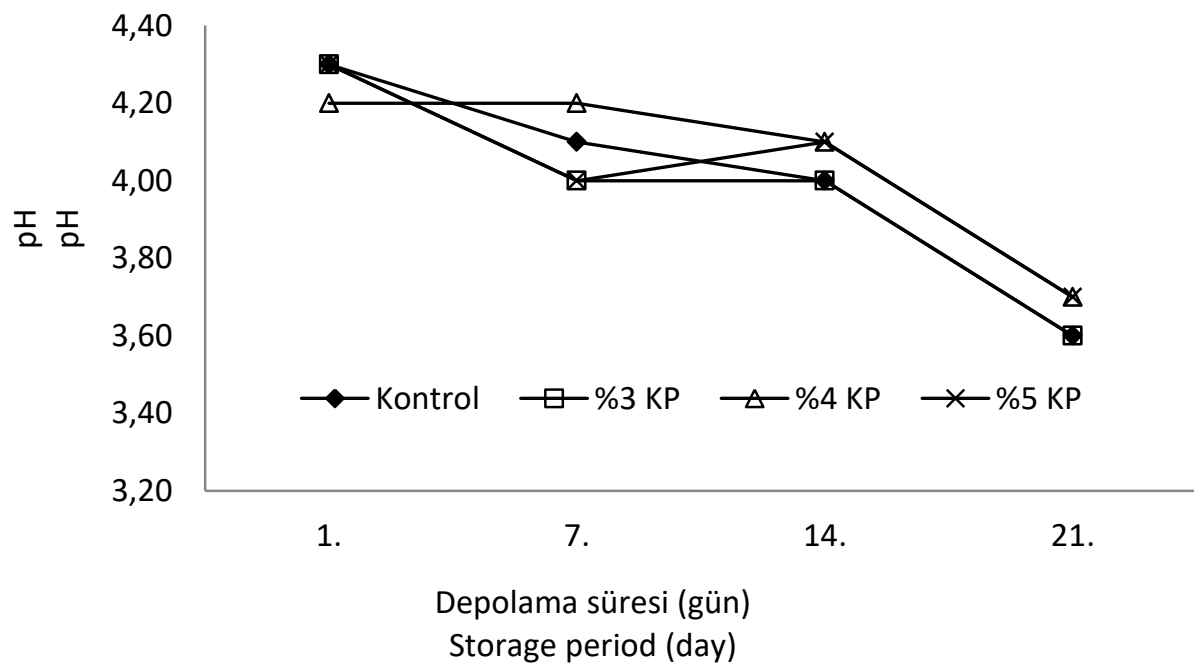

Şekil 1. Yoğurt tipi x depolama periyodu interaksiyonu bakımından deneme yoğurtlarında $\mathrm{pH}$ değişimi. KP: Keçiboynuzu pekmezi içeren yoğur

Figure 1. $\mathrm{pH}$ changes of yoghurt samples with regard to interaction of yoghurt type $\mathrm{x}$ storage period. CM: Carob molasses yoghurt

Tüm deneme yoğurtlarının $\mathrm{pH}$ değerinde, \%4 KP içeren yoğurt hariç depolama periyodunun 7. gününe kadar hızlı bir azalma, 7-14. günler arası duraklama, depolama periyodunun 21. gününde ise tekrar hızlı bir düşüş görülmüştür (Şekil 1). Depolama süresi boyunca $\mathrm{pH}$ değerinde görülen bu azalma benzer şekilde Tarakçı ve Küçüköner (2003), Atasoy (2009), Çelik (2010), Karaca ve ark.,
(2012), tarafından yapılan çalışmalarda da gözlemlenmiştir. Deneme yoğurtlarından \%4 KP içeren yoğurdun $\mathrm{pH}$ değeri depolama periyodu boyunca daha yüksek seyretmesi ve periyodun sonunda \%4 ve \%5 KP örneklerinin $\mathrm{pH}$ değerinin 3.7 olması, yoğurdun raf ömrünü olumsuz yönde etkilemektedir. 


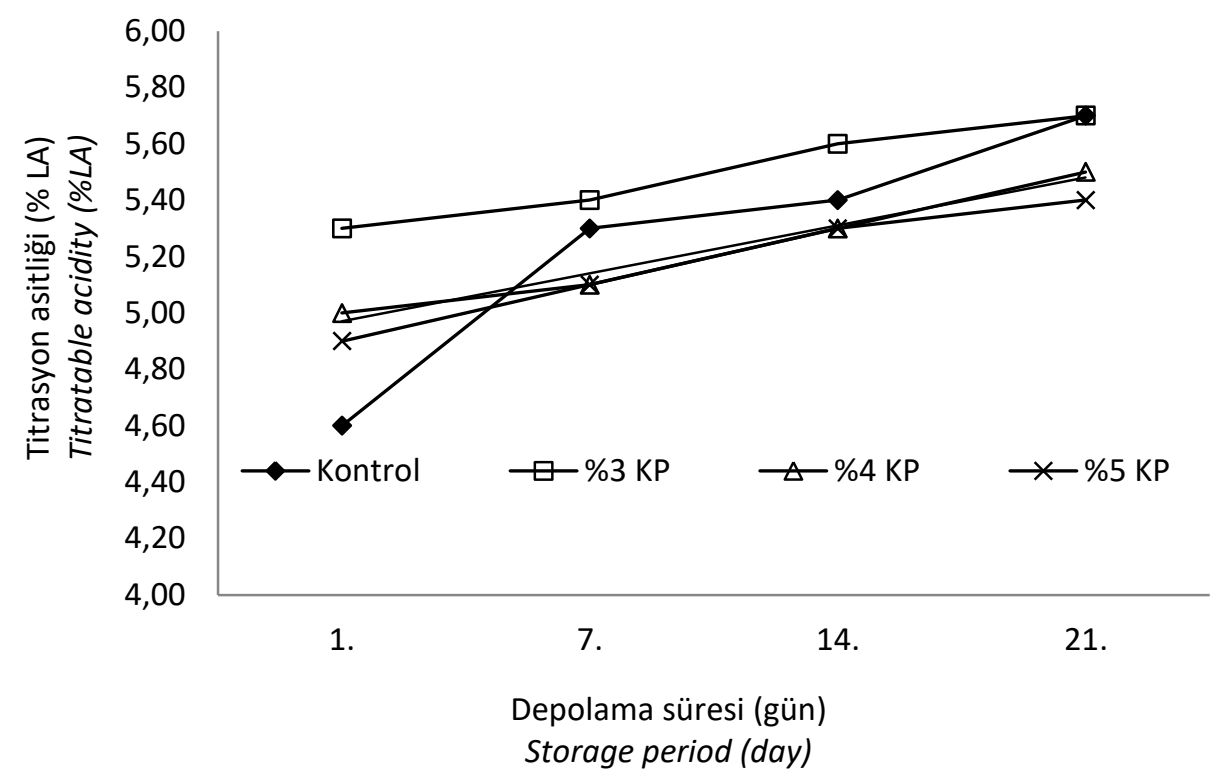

Şekil 2. Yoğurt tipi $x$ depolama periyodu interaksiyonu bakımından deneme yoğurtlarında titrasyon asitliği değişimi.KP: Keçiboynuzu pekmezi içeren yoğurt

Figure 2. Titratable acidity changes of yoghurt samples with regard to interaction of yoghurt type $x$ storage period. CM: Carob molasses yoghurt

Deneme yoğurtlarının titrasyon asitlik Özetle meyveli yoğurt bileşiminde kullanılan KP değerlerinin depolama periyodu boyunca arttı̆̆ı gözlemlenmiştir. Depolama periyodunun 7. gününe kadar kontrol yoğurdunda hızlı bir artış gözlenirken; KP örneklerinin kontrole göre daha yavaş bir artış söz konusudur. Periyot sonunda, \%3 KP örneğinin kontrol ile aynı titrasyon asitliği değerine sahip olduğu, \%4 ve 5 KP örneklerinin ise diğerlerine göre daha düşük titrasyon asitliği değerine sahip olduğu gözlemlenmiştir (Şekil 2). oranı arttıkça titrasyon asitliğinin azaldığı tespit edilmiştir. Atasoy (2009) çalışmasında farklı oranlarda $\mathrm{KP}(2.5,5,7.5$ ve $10 \mathrm{~mL}$ keçiboynuzu pekmezi/ $100 \mathrm{~mL}$ süt) örneklerinde titrasyon asitliği yönünden benzer sonuçlar elde ettikleri; Karaca ve ark. (2012) ise KP (\%6, 10 ve 14) ilave edilen yoğurtlarda depolama süresi boyunca pekmez oranındaki artışa paralel olarak titrasyon asitliğinde de artış gözlemlendiği belirtilmektedir.

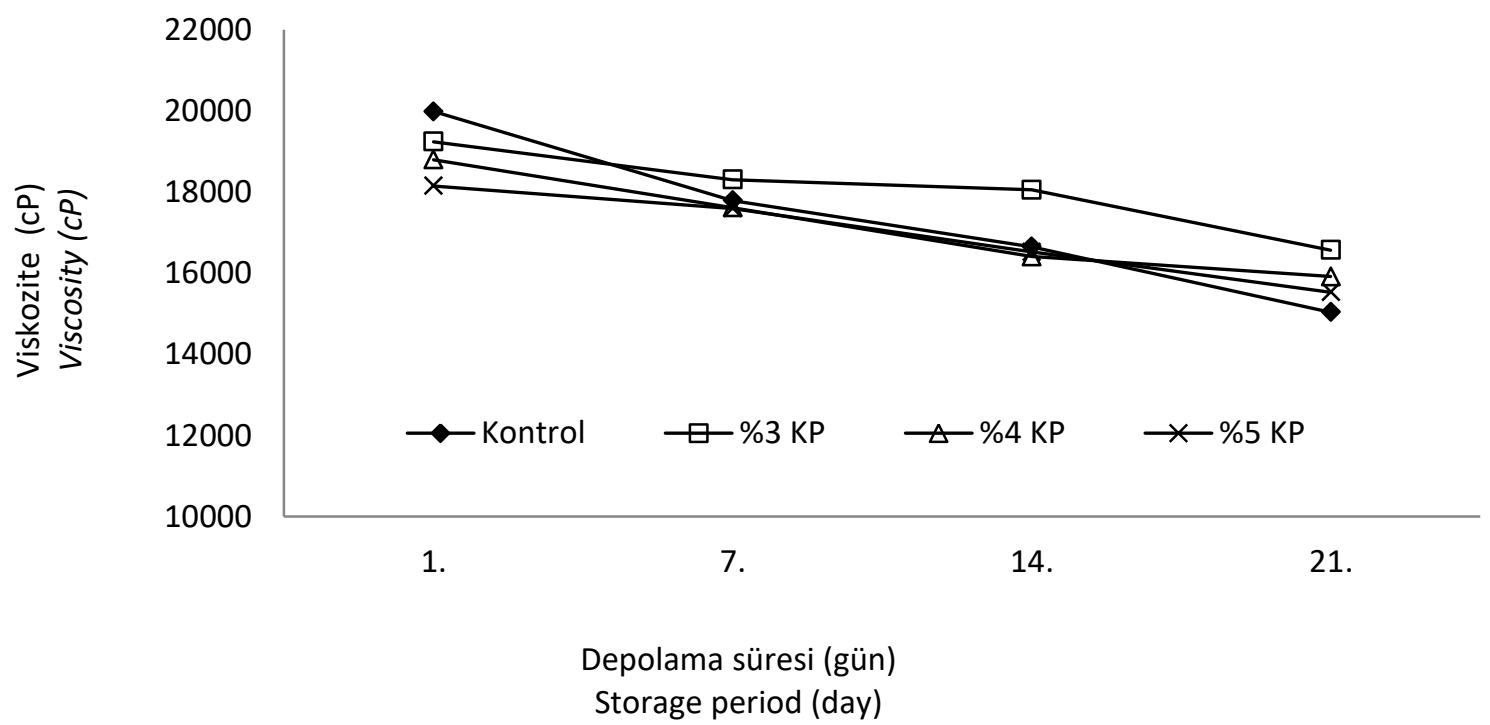

Şekil 3. Yoğurt tipi x depolama periyodu interaksiyonu bakımından deneme yoğurtlarda depolama periyodu boyunca viskozite değişimi. KP: Keçiboynuzu pekmezi içeren yoğurt

Figure 3. Viscosity changes of yoghurt samples with regard to interaction of yoghurt type $x$ storage period. CM: Carob molasses yoghurt 
Depolama periyodu boyunca deneme yoğurtlarının viskozite değerlerinde, hızlı bir düşüş gözlemlenmiştir. Depolama periyodu başlangıcında kontrol yoğurdunun en yüksek viskozite değerine sahip olduğu; depolama periyodu sonunda ise en düşük viskozite değerine sahip olduğu tespit edilmiştir. Ayrıca genel olarak pekmez ilavesi oranı arttıkça viskozite değerinin azaldığı gözlemlenmiştir (Şekil 3). Bu durumun keçiboynuzu pekmezinin süt proteinlerini seyreltme kaynaklandığı düşünülmektedir. Karaca ve ark. (2012) çalışmasında benzer sonuçlara rastlanmaktadır. Ayrıca aynı çalışmada KP ilave edilen yoğurtların, üzüm ve dut pekmezi ilave edilen yoğurtlara göre viskozite yönünden daha iyi sonuçlar oluşturduğu belirtilmektedir. Nitekim keçiboynuzu pekmezinin (doğru oranlarda kullanıldığı takdirde) yüksek gum içeriğine sahip olması, pekmez-yoğurt karışımlarının fizikokimyasal özellikleri üzerinde olumlu etki oluşturabilmektedir. Çelik (2010) çalışmasında KP ilave oranındaki artışın, kontrol yoğurduna göre meyveli yoğurtların viskozite değerini azalttığını belirtmektedir. Aynı çalışmada KP ilave edilmiş meyveli yoğurtların viskozite değerlerinin 28 günlük depolama periyodu sonunda kontrol yoğurduna göre daha düşük olduğunu bildirmektedir.

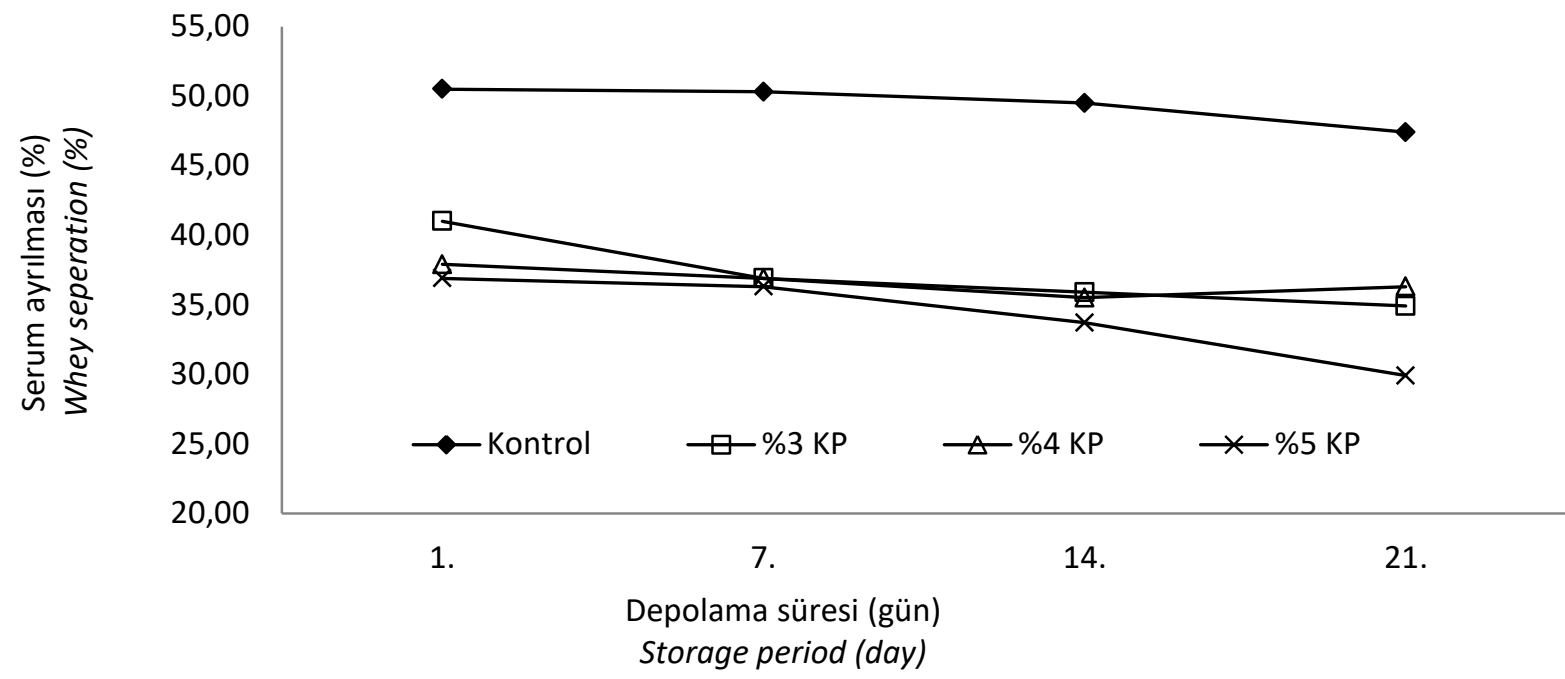

Şekil 4. Yoğurt tipi x depolama periyodu interaksiyonu bakımından deneme yoğurtlarda depolama periyodu boyunca serum ayrılması değişimi

KP: Keçiboynuzu pekmezi içeren yoğurt

Figure 4. Whey separation changes of yoghurt samples with regard to interaction of yoghurt type $x$ storage period CM: Carob molasses yoghurt

Depolama periyodu boyunca tüm deneme yoğurtlarının viskozite değerlerinde \%4 KP örneği hariç azalma gözlenmiştir. \%4 KP örneğinde depolama periyodunun 14. gününden 21. gününe kadar viskozite değerinde artış gözlemlenmiştir. KP örneklerinde serum ayrılması kontrol yoğurduna oranla daha düşük düzeyde bulunmuştur. Diğer bir deyişle KP katkısı, deneme yoğurtlarında su salmayı belli bir oranda önlemiştir. Bu durumun, keçiboynuzu pekmezinin su tutma kapasitesi yüksek olan protein ve indirgen şeker içeriğinden kaynaklandığı düşünülmektedir. Karaca ve ark. (2012) çalışmasında benzer sonuçlara rastlanmaktadır ve kullanılan pekmez çeşitleri arasında en az serum ayrımasının KP örneklerinde görüldüğü belirtilmektedir. Çelik ve Bakırcı (2003) dut pekmezi ilavesinin ve Atasoy (2009) ise KP ilavesinin meyveli yoğurtlarda kontrol yoğurduna göre serum ayrılmasını genel anlamda arttırdığını ve pekmez oranı arttıkça serum ayrılmasının da arttığını belirtmektedir. 


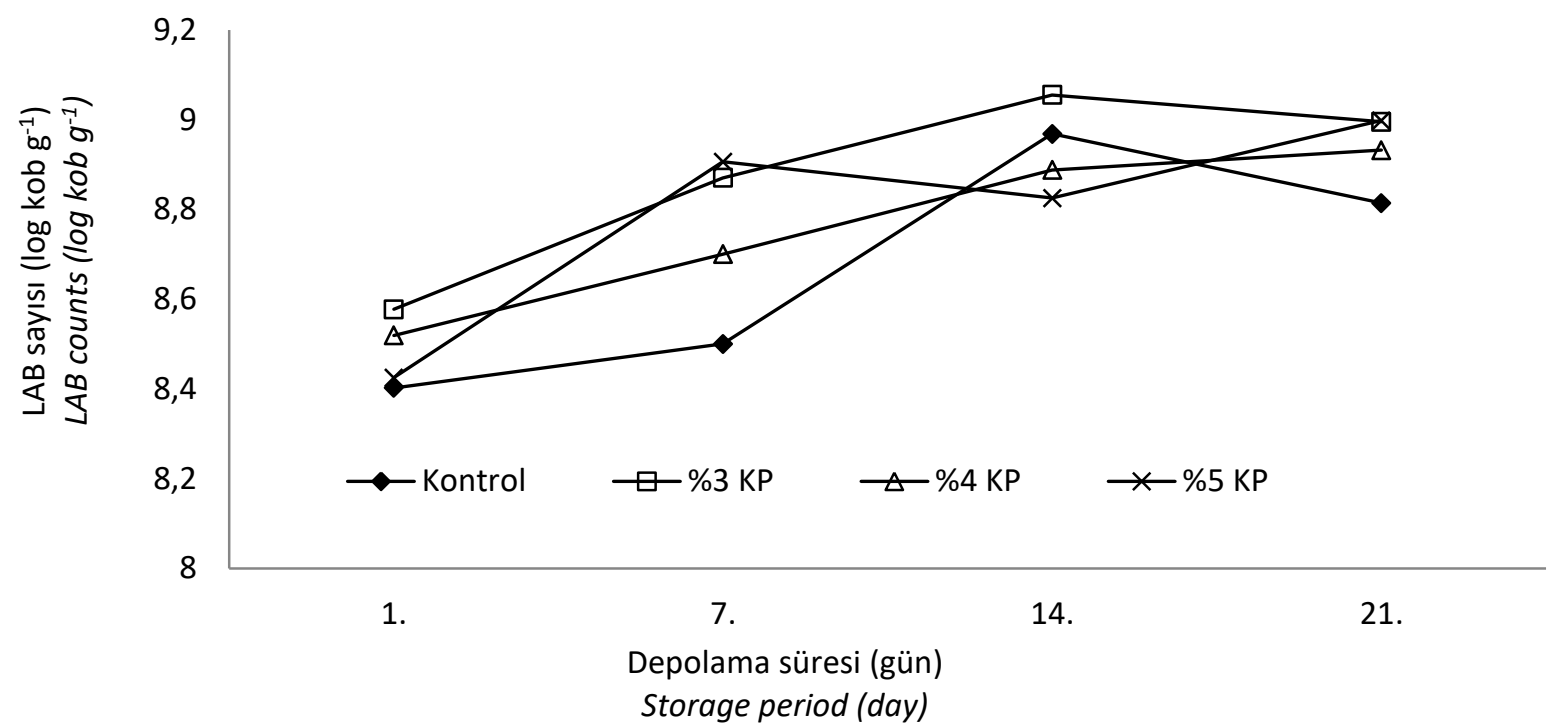

Şekil 5. Yoğurt tipi $x$ depolama periyodu interaksiyonu bakımından deneme yoğurtlarda depolama periyodu boyunca laktik asit bakteri (M17 agar) sayıları değişimi. KP: Keçiboynuzu pekmezi içeren yoğurt

Figure 5. Counts of lactic acid bacteria (M17 agar) of yoghurt samples with regard to interaction of yoghurt type $x$ storage period. CM: Carob molasses yoghurt

Bilindiği gibi yoğurt üretiminde YC-350 (ChrHansen) kültürü Streptococcus thermophilus ve Lactobacillus delbrueckii subsp. bulgaricus bakterilerin bileşiminden (1:1 veya 3:1) oluşan kültür kullanılmaktadır. M17 agar besiyeri daha çok kok şekilli laktik asit bakterilerinin (LAB) çoğalmasına uygun olduğu için bu ortamda Str. thermophilus bakterisinin gelişmesi beklenmektedir. Şekil 5 incelendiğinde depolama periyodu boyunca kontrol grubuna oranla, genel olarak pekmez içeren yoğurtlarda LAB sayısı yüksek bulunmuştur. $B u$ durum ilave edilen pekmezin, ortamın $\mathrm{pH}$ değerine LAB'ların gelişmesini olumlu yönde etkileyecek düzeyde katkıda bulunmasından ve pekmezin asitlik gelişimini dengeleyici olarak rol oynamasından kaynaklanmış olduğu düşünülmektedir. Benzer şekilde Atasoy (2009) KP örneklerinde Str. thermophilus sayısında depolamanın 14. gününe kadar artış, 14. gününden sonra hızlı bir azalışın gözlemlendiği belirtilmektedir. Depolama periyodunun başlangıcında kontrol, \%3, 4 ve $5 \mathrm{KP}$ örneklerinde sırasıyla $8.402 \mathrm{log}$ kob/g, $8.577 \mathrm{log}$ kob/g, 8.519 log kob/g ve 8.425 log kob/g LAB tespit edilmiştir. Kontrol ve \%3 KP örneği haricinde depolama süresi boyunca LAB sayısında artış tespit edilmiştir. Kontrol ve \%3 KP örneğinde depolamanın 14-21. günleri arasında $L A B$ sayısında azalış gözlemlenmiştir. Depolama süresi sonunda kontrol örneğinde $8.814 \log \mathrm{kob} / \mathrm{g}$, \%3 KP örneğinde 8.988 log kob/g, \%4 KP örneğinde $8.932 \mathrm{log} \mathrm{kob} / \mathrm{g}$ ve \%5 KP örneğinde $8.988 \mathrm{log}$ $\mathrm{kob} / \mathrm{g}$ LAB içerdiği tespit edilmiştir. Çelik ve ark. (2009) andız pekmezi içeren meyveli yoğurtlarda depolama süresinin 7. gününe kadar nispi bir artış, 7. gününden sonra $L A B$ sayısında azalma gözlemlenerek 8.4-8.6 log kob/g seviyelerine indiği belirtilmektedir. 


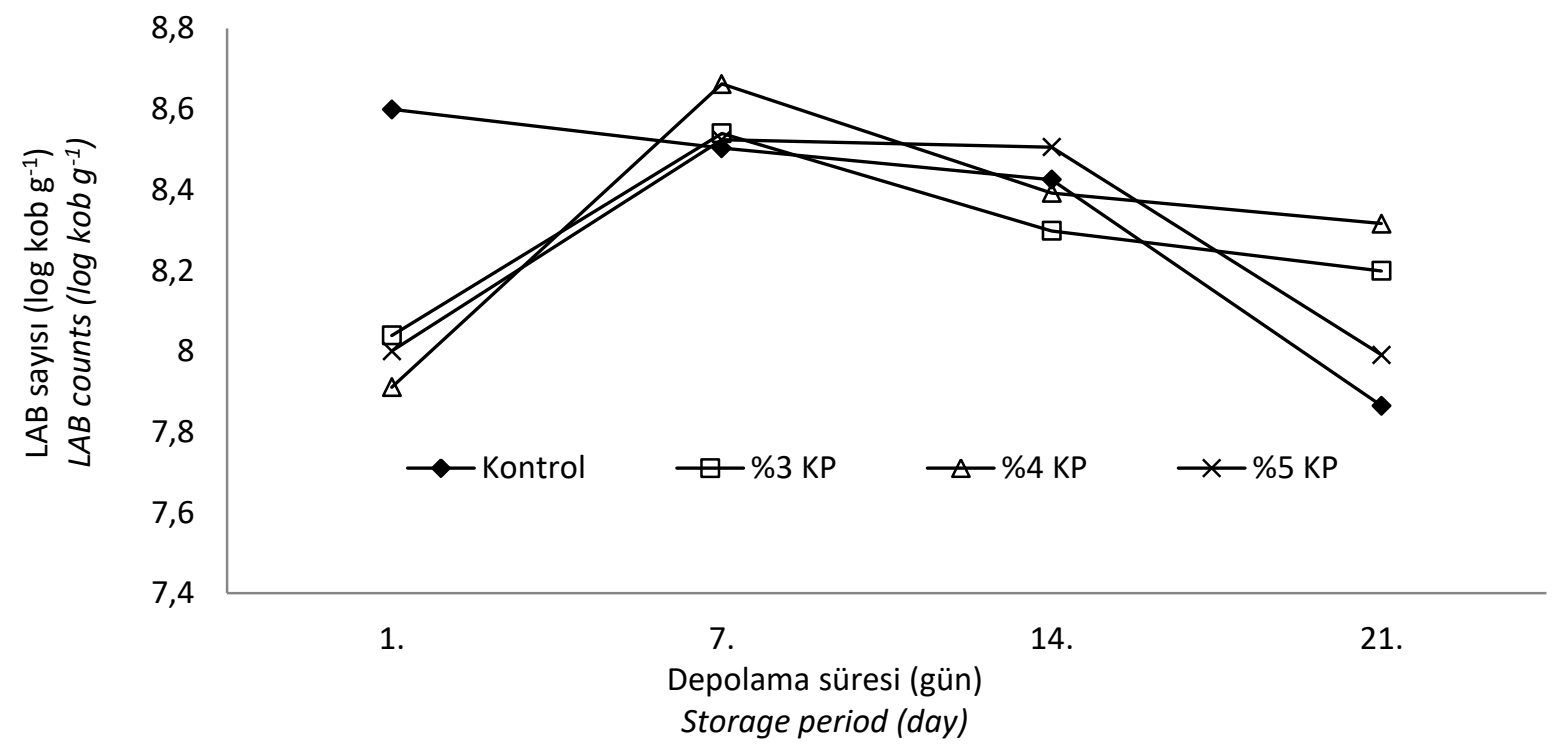

Şekil 6. Yoğurt tipi x depolama periyodu interaksiyonu bakımından deneme yoğurtlarda depolama periyodu boyunca laktik asit bakteri (MRS agar) sayıları değişimi. KP: Keçiboynuzu pekmezi içeren yoğurt

Figure 6. Counts of lactic acid bacteria (MRS agar) of yoghurt samples with regard to interaction of yoghurt type $x$ storage period. CM: Carob molasses yoghurt

MRS agar besiyerinde daha çok basil formda bulunan LAB'nin geliştiği bilinmektedir. Bu bağlamda, MRS agar besiyerinde daha çok yoğurt kültüründe bulunan $L b$. delbrueckii subsp. bulgaricus bakterisinin gelişmesi beklenmektedir. Şekil 6'da görüldüğü gibi kontrol yoğurdu haricinde KP örneklerde depolama süresinin 7. gününe kadar LAB sayısında hızlı bir artış, 7-14. günler arasında LAB sayısında azalma görülmüştür. Periyodun 14-21. günlerinde ise kontrol ve \%5 KP örneğinde diğer yoğurt örneklerine göre LAB sayısında daha hızlı bir azalma gözlemlenmiştir. Depolama periyodu sonunda kontrol, \%3, 4 ve $5 \mathrm{KP}$ örneklerinin $\mathrm{LAB}$ sayıları sırasıyla $7.865,8.199,8.317$ ve $7.84 \mathrm{log}$ kob/g olarak tespit edilmiştir. Benzer şekilde Atasoy (2009) ile Çelik ve ark. (2009) KP-yoğurt ve andız pekmezi-yoğurt karışımlarında $L b$. delbrueckii subsp. bulgaricus sayısında depolamanın 7. gününe kadar artış, ardından hızlı bir azalışın gözlemlendiği belirtilmektedir.

Çizelge 3. Deneme yoğurtlarının duyusal değerlendirmelerine ilişkin istatiksel analiz sonucu oluşan gruplar Table 3. Statically analyses groups according to the sensory evaluation of yoghurt samples

\begin{tabular}{|c|c|c|c|c|c|c|}
\hline $\begin{array}{l}\text { Yoğurt Tipi } \\
\text { Yoghurt Types }\end{array}$ & $\begin{array}{c}\text { Görünüş } \\
\text { Appearance }\end{array}$ & $\begin{array}{c}\text { Kıvam (kaşık) } \\
\text { Consistency (Spoon) }\end{array}$ & $\begin{array}{c}\text { Kıvam (Ağız) } \\
\text { Consistency (Mouth) }\end{array}$ & $\begin{array}{l}\text { Koku } \\
\text { Odour }\end{array}$ & $\begin{array}{c}\text { Tat } \\
\text { Aroma }\end{array}$ & $\begin{array}{c}\text { Tatlılık } \\
\text { Sweetness }\end{array}$ \\
\hline $\begin{array}{l}\text { Kontrol } \\
\text { Control }\end{array}$ & $2.21 \pm 0.06$ & $2.18 \pm 0.06$ & $2.04 \pm 0.09$ & $2.24 \pm 0.06$ & $2.21 \pm 0.04$ & - \\
\hline $\begin{array}{l}\text { \%3 KP - Yoğurt } \\
\% 3 \text { CM - Yoghurt }\end{array}$ & $2.12 \pm 0.06$ & $2.10 \pm 0.06$ & $1.95 \pm 0.09$ & $2.04 \pm 0.06$ & $2.08 \pm 0.04$ & $1.53 \pm 0.11$ \\
\hline $\begin{array}{l}\text { \%4 KP - Yoğurt } \\
\% 4 \text { CM - Yoghurt }\end{array}$ & $2.10 \pm 0.06$ & $2.10 \pm 0.06$ & $2.07 \pm 0.09$ & $2.10 \pm 0.06$ & $2.08 \pm 0.04$ & $1.77 \pm 0.11$ \\
\hline $\begin{array}{l}\text { \%5 KP - Yoğurt } \\
\% 5 \text { CM - Yoghurt }\end{array}$ & $1.99 \pm 0.06$ & $2.07 \pm 0.06$ & $2.04 \pm 0.09$ & $2.02 \pm 0.06$ & $2.10 \pm 0.04$ & $1.93 \pm 0.11$ \\
\hline
\end{tabular}

KP: Keçiboynuzu pekmezi içeren yoğurt

CM: Carob molasses yoghurt

Deneme yoğurtlarının görünüş puanları 1.992.21 arasında değişmiştir (Çizelge 2). Görünüş yönünden en yüksek puanı kontrol yoğurdu alırken bunu ikinci sırada \%3 KP örneği takip etmektedir. En düşük puanı ise \%5 KP örnek almıştır. KP oranındaki artışın deneme yogurt örneklerinde renk değerlerini olumsuz yönde etkilemesinin nedeni; pekmezin meyveli yoğurtlarda yoğun bir renk oluşturmasından ve KP oranındaki artışının belirli bir düzeyden sonra 
karşımın fizikokimyasal özelliklerini etkileyerek karışımda istenmeyen görünüş kusurlarına sebep olmasından kaynaklandığı düşünülmektedir.

Duyusal testler sonucunda deneme yoğurtlarının kıvam (kaşık ve ağız) puanlarının 1.95- 2.19 arasında değiştiği belirlenmiştir. Yoğurtlardan en yüksek kıvam puanını kontrol yoğurdu alırken; en düşük kıvam puanını \%5 KP örneği almıştır. Genel olarak KP oranının artışına bağlı olarak karışımların kıvam yönünden olumsuz etkilendiği tespit edilmiştir. Eroğlu ve ark. (2016), pekmez ilavesinin içerdiği polisakkaritlerin karışımdaki proteinler arasındaki etkileşimi azaltarak kıvam, yapışkanlık, viskozite gibi çeşitli duyusal ve reolojik parametrelerini olumsuz yönde etkilediğini belirtmektedir. Benzer şekilde Atasoy (2009), KP ilavesinin genel olarak karışımların yapı ve tekstürel özelliklerini kontrol yoğurduna göre olumsuz yönde etkilediğini bildirmektedir.

Koku yönünden en yüksek puanı kontrol yoğurdu alırken bunu sırasıyla \%3, 4 ve $5 \mathrm{KP}$ örnekleri takip etmektedir. $\mathrm{Bu}$ durum keçiboynuzu pekmezinin yoğurt-pekmez karışımlarında panelistler tarafından beğenilmeyen bir koku oluşturduğunu göstermektedir. Nitekim KP, meyvesinden kaynaklı yoğun kokuya sahip bir üründür ve bu koku pekmez üretimi sırasında her ne kadar azalsa da son üründe hissedilir düzeyde kalmaktadır. Tat yönünden incelendiğinde en yüksek puanı (2.21) kontrol yoğurdu alırken, bunu 2.11 puan ile \%5 KP örneği izlemekte, \%3 ve 4 KP örnekleri ise birbirine yakın puanlar alarak 2.08 puan ile panelistler tarafindan en az seviyede beğenilmiştir. Diğer duyusal özelliklerden farklı olarak KP oranındaki artışın karışımın tat özelliğini olumlu yönde etkilemesinin sebebinin ise pekmezin şeker içeriğinden kaynaklanmış olabileceği düşünülmektedir. Benzer şekilde tatlılık yönünden incelendiğinde de KP oranındaki artışın meyveli yoğurtların tatlılık özelliğini olumlu yönde etkilemesinin aynı sebepten kaynaklanmış olabileceği düşünülmektedir. Karaca ve ark. (2012), pekmez oranındaki \%10'luk artışa kadar pekmez ilavesinin karışımların aroma özelliklerinin artırdığını, \%14'lük pekmez ilavesinin ise aroma profilini olumsuz yönde etkilediğini belirtmektedir. Aynı çalışmada panelistler tarafından üzüm ve dut pekmezi ile hazırlanmış meyveli yoğurtların KP örneklerinden daha çok beğenildiği ifade edilmiştir.

\section{Sonuçlar}

Endüstriyel olarak üretilecek bir ürünün tüketiciye hitap edebilmesi ve tüketicinin o üründen beklentilerini karşılayabilmesi çok önemli bir husustur. Meyveli yoğurt karışımlarında da son ürünün hem karışımda kullanılan ingrediyentlerin renk, tat ve koku gibi belli başlı özelliklerinin yansıtabilir düzeyde olması hem de bu oranının karışımın yapı, tekstür, kıvam, görünüm gibi diğer duyusal özellikleri, fizikokimyasal yapısı ve mikrobiyolojik özellikleri üzerinde olumsuz etki oluşturmayacak düzeyde olması gereklidir. Aksi takdirde elde edilecek son üründe kalite kusuru olarak tanımlanan sorunlar ortaya çıkabilmektedir. Bu çalışma sonunda elde edilen fizikokimyasal, mikrobiyolojik ve duyusal verilere göre KP içeren meyveli yoğurt karışımları için en uygun oran $\% 3$ olarak belirlenmiştir.

\section{Ekler}

$\mathrm{Bu}$ çalışmanın yürütülmesinde katkı sağlayan Betül GÜÇ ve Pınar CEYLAN’a teşekkür ederiz.

\section{Kaynaklar}

Aksu M. I., Nas, S., 1996. Dut pekmezi üretim tekniği ve çeşitli fiziksel-kimyasal özellikleri. Gıda, 21 (2): 83-88.

AOAC, 1990. Official methods of analysis, 15th edn. Washington, DC: Association of official analytical chemists.

Atasoy, A. F., 2009. The effects of carob juice concentrates on the properties of yoghurt. International Journal of Dairy Technology, 62 (2): 228-233.

Bodyfelt, F.W., Tobias, J., Trout, G.M., 1988. The sensory evaluation of dairy products. Van Noastrand Reinhold, New York, s: 227-299.

Çelik, S., Bakırcı, I., 2003. Some properties of yoghurt produced by adding mulberry pekmez (concentrated juice). International Journal of Dairy Technology, 56 (1): 26-29.

Çelik, Ş., Durmaz, H., Şat, i. G., Şenocak, G., 2009. Andız pekmezi içeren set tipi yoğurtların bazı fizikokimyasal ve mikrobiyolojik özellikleri. Gıda Dergisi, 34 (4): 213- 
218.

Çelik, Ş., 2010. Production and evaluation of set-type yoghurts with carob bean molasses. Milchwissenschaft, 65 (4): 400-403.

Eroğlu, A., Bayrambaş, K., Eroğlu, Z., Toker, O. S., Yilmaz, M. T., Karaman, S., Dogan, M., 2016. Steady, dynamic, creep/recovery, and textural properties of yoghurt/molasses blends: Temperature sweep tests and applicability of Cox-Merz rule. Food Science and Technology International, 22 (1): 31-46.

Gassem A.M., Frank F.J., 1991. Physical properties of yogurt made from milk treated with proteolytic enzyme. Journal of Dairy Science, 74 (5): 1503-1511.

Karaca O.B., Saydam I.B., Güven M., 2012. Physicochemical, mineral and sensory properties of set-type yoghurts produced by addition of grape, mulberry and carob molasses (Pekmez) at different ratios. International Journal of Dairy Technology, 65 (1): 111-117.

Karaca, O.B., 2013. Effects of different prebiotic stabilisers and types of molasses on physicochemical, sensory, colour and mineral characteristics of probiotic set yoghurt. International Journal of Dairy Technology, 66 (4): 490-497.

Kumar, P., ve Mishra, H.N., 2004. Yoghurt powder-A review of process technology, storage and utilization, Food and Bioproducts Processing , 82 (2): 133-142.

Kurt, A., Çakmakçı, S., Çağlar, A., 1996. Süt ve mamülleri muayene ve analiz metotları rehberi. Atatürk Üniversitesi, Ziraat Fakültesi, Yayın No:18, Erzurum.

Öztürk, B., Öner M.D., 1999. Production and evaluation of yogurt with concentrated grape juice. Journal of Food Science, 64 (3): 530-532.

Rodarte, C.W., Galvan, M.V., Farres, A., Galardo, F., Marshall, V.E., Garibay, M.G., 1993. Yogurt production from reconstituted skim milk powders using different polymer and non-polymer forming stareter cultures. Journal of Dairy Research. 60 (2): 247-254.

Rybka, S., Kailasaphaty, K., 1996. Media for enumeration of yogurt bacteria. International Dairy Journal, 6 (8-9): 839-850.

Sader, A.P.O., Oliveira, S.G., Berchielli, T.T., 2004. Application of kjeldahl and dumas combustion methods for nitrogen analysis. Archives of Veterinary Science, 9 (2): 73-79.

Tamime, A.Y., Robinson, R.K., 2007. Yogurt science and technology, Pergamon Press, England.

Tarakçı, Z., Küçüköner, E. 2003. Physical, chemical, microbiological and sensory characteristics of some fruit-flavored yoghurt. YYÜ. Vet. Fak. Derg., 14 (2): 10-14.

Yıldız, N., Bircan, H., 1991. Araştırma ve deneme metotları, Atatürk Üniversitesi Yayınları, No: 697, Ziraat Fak. No: 30, Ders Kitapları Serisi No: 57, Erzurum, s: 7078. 